\title{
Os "combatentes da paz"- a participação dos comunistas brasileiros na Campanha Pela Proibição das Armas Atômicas (1950)
}

"Combatants for peace"-
the participation of Brazilian communists in the
Campaign for the Banning of Atomic Weapons (1950)
Jayme Ribeiro

No início da década de 1950, militantes comunistas de várias partes do mundo, do Brasil inclusive, lançaram-se numa campanha com um objetivo: salvaguardar a paz mundial. É bem provável que isso cause alguma estranheza ao leitor destas páginas. No Brasil, o Partido Comunista (PCB), não se pode esquecer, fora criado em março de 1922 com o objetivo de fazer a revolução. Desde a sua fundação, formulou uma série de políticas - em períodos que acreditava serem mais oportunos para suas ações revolucionárias - voltadas para a tomada

Jayme Lúcio Fernandes Ribeiro é doutor em história social e professor da UERJ e da Universidade Gama Filho (jaymelucio@uol.com.br).

Artigo recebido em 30 de junho e aprovado para publicação em 19 de setembro de 2008.

Nota do autor: Este artigo é parte de minha dissertação de mestrado apresentada à Universidade Federal Fluminense (UFF).

Estudos Históricos, Rio de Janeiro, vol. 21, nº 42, julho-dezembro de 2008, p. 261-283. 
do poder por diversas vias, incluindo a das armas. O objetivo dos fundadores do PCB era claro: conquistar o poder político por intermédio do proletariado e transformar a sociedade capitalista em comunista (Pereira, 1980). No entanto, a partir do fim da Segunda Guerra Mundial e, sobretudo, do início da Guerra Fria, os comunistas brasileiros passaram a desenvolver diversas campanhas em favor da paz, articulando sua política revolucionária - luta armada para a derrubada do governo - a uma política de luta pela paz no âmbito internacional.

O objetivo deste artigo é reconstituir a Campanha pela Proibição das Armas Atômicas adotada pelo PCB no início da década de 1950 e mostrar como os comunistas brasileiros a desenvolveram. Através de imagens, crenças e idéias, tenta-se apresentar os principais fatores que sustentaram tal campanha. $\mathrm{O}$ artigo preocupa-se também em mostrar que, a partir do pós-guerra, a União Soviética procurou veicular no imaginário social a imagem de um país amante da paz e defensor dos povos.

\section{Os comunistas e o Movimento pela Paz}

A partir de 1947, ano em que se iniciou a Guerra Fria, a União Soviética, sob a liderança de Stalin, lançou aos partidos comunistas de todo o mundo uma nova "linha geral" (Claudin, 1970). A nova orientação consistia em formar uma ampla frente antiamericana e impor aos Estados Unidos um arranjo mundial satisfatório aos interesses soviéticos, que lhes permitisse avançar nas pesquisas nucleares, obter o controle da corrida armamentista e barrar o desenvolvimento norte-americano nesse campo.

O movimento organizado que obteve maior destaque dentro da nova "linha geral" foi o Movimento pela Paz, também chamado Luta pela Paz. O movimento começou em 1948, quando se realizaram na Polônia, em agosto, o Congresso Mundial dos Intelectuais pela Paz, e na França, em novembro, o Congresso Nacional dos Combatentes da Paz. Novos passos foram dados nos anos seguintes: em 1949 realizou-se o I Congresso Mundial da Paz, em Paris e Praga, e em março de 1950 o comitê do Congresso Mundial dos Partidários da Paz, reunido em Estocolmo, na Suécia, lançou o Apelo de Estocolmo, dando início à Campanha pela Proibição das Armas Atômicas. O objetivo era coletar assinaturas em diversos países para serem enviadas à $\mathrm{ONU}$, manifestando a posição de milhões de pessoas a favor da paz mundial.

Para a compreensão do contexto internacional em que foi criado o Movimento pela Paz e, posteriormente, a ele foi incorporada a Campanha pela Proibição das Armas Atômicas, vários episódios são significativos: o envio ao Uruguai de bombardeiros do Comando Aéreo Estratégico dos Estados Unidos, armados 
com dispositivos nucleares, em uma demonstração de força, quando da posse do presidente uruguaio em fevereiro de 1947, o lançamento da Doutrina Truman e do Plano Marshall naquele mesmo ano, a crise de Berlim (junho de 1948 - maio de 1949), a conclusão da Organização do Tratado do Atlântico Norte (Otan) em abril de 1949, o comunicado da agência de informação Tass, em 25 de setembro de 1949, confirmando a explosão de uma bomba atômica soviética em abril daquele ano e revelando que a União Soviética possuía a bomba desde 1947, e finalmente o início da Guerra da Coréia, em junho de 1950.

Nesse contexto, em novembro de 1949, na reunião do Kominform, a "luta pela paz" foi definida como tarefa central do movimento comunista, à qual deveriam subordinar-se todas as outras tarefas e objetivos. Acreditava-se então numa possível "ação direta" do imperialismo norte-americano contra a União Soviética. Segundo os líderes do Kominform, os soviéticos enfrentavam uma grave ameaça diante da escalada armamentista dos Estados Unidos, e especialmente diante de seus arsenais atômicos. O objetivo prioritário dos revolucionários comunistas, portanto, era conquistar uma paz "sólida e duradoura" em detrimento de novas revoluções socialistas. De acordo com Stalin,

o atual movimento pela paz se propõe a mobilizar as massas populares na luta pela conservação da paz, por conjurar uma nova guerra mundial. Por conseguinte, não tende a derrubar o capitalismo e a instaurar o socialismo: se limita a fins democráticos de luta pela manutenção da paz (Claudin, 1970: 528).

Ao realizar sua terceira sessão plenária em março de 1950, o comitê do Congresso Mundial dos Partidários da Paz pretendia fazer um balanço das lutas pela paz que se desenvolveram e se intensificaram nos primeiros meses do ano, $\mathrm{e}$ trocar experiências para prossegui-las de modo mais elevado, com a finalidade de conjurar as ameaças de guerra que então se agravavam. $\mathrm{O}$ comitê adotou importantes resoluções para a luta dos partidários da paz em todo o mundo, que foram transcritas no Brasil pelo jornal Voz Operária (1/4/1950, p. 4):

1) Chamamos todos os homens de boa vontade para um novo Congresso Mundial da Paz, a realizar-se na Itália no $4^{\circ}$ trimestre de 1950.

2) Convidamos para este Congresso todas as coletividades sociais, religiosas e culturais, todas as pessoas de bem, quaisquer que sejam as suas opiniões sobre a origem da atual tensão internacional, que 
se preocupam e desejam sinceramente o restabelecimento das relações pacíficas entre as nações.

3) Submetemos a todos, como ponto para um acordo, a proibição da arma atômica e a condenação de qualquer governo que, em primeiro lugar, dela fizer uso.

Ainda segundo a Voz Operária, na ocasião o comitê lançou também um apelo assinado por seu presidente, o cientista francês Fréderic Joliot-Curie, nos seguintes termos:

Exigimos a proibição absoluta da arma atômica, arma de terror e extermínio em massa de populações.

Exigimos ao mesmo tempo o estabelecimento de um rigoroso controle internacional que assegure a aplicação da medida de interdição.

Consideramos que o governo que primeiro utilizar a arma atômica, não importa contra que país, terá cometido um crime contra a humanidade e deverá ser considerado criminoso de guerra.

nem este apelo.

Pedimos a todos os homens de boa vontade que assi-

O Apelo de Estocolmo, como ficou conhecido, lançado em 15 de março de 1950, mobilizou comunistas de todo o mundo, que se engajaram com disciplina e grande determinação na Campanha pela Proibição das Armas Atômicas. Aqueles que participavam ativamente da campanha colhendo assinaturas em cópias do apelo, em sua maioria militantes comunistas, eram chamados de "combatentes da paz".

Importa ressaltar que o Movimento pela Paz incorporou a Campanha pela Proibição das Armas Atômicas, mas não se restringiu a ela. Protestos contra a Otan, contra a Guerra da Coréia, contra o envio de soldados brasileiros para a Coréia, apelos em prol do desarmamento geral, de um pacto de paz entre as cinco grandes potências - Estados Unidos, União Soviética, China, Inglaterra e França estavam vinculados ao movimento maior da Luta pela Paz. A campanha contra as armas atômicas, de menor amplitude, dirigia seus esforços especificamente para a proibição da utilização desse tipo de arma por qualquer país e para a eliminação dos arsenais atômicos existentes. Além disso, a questão da proibição das armas nucleares em conflitos internacionais percorreu as demais campanhas. Uma campa- 
nha não anulava a outra, pois, para garantir uma paz sólida e duradoura, o primeiro passo era proibir a utilização das armas atômicas em quaisquer guerras.

Atendendo ao Apelo de Estocolmo, cada país tinha uma cota de assinaturas que deveria coletar para enviar ao II Congresso Mundial da Paz. No Brasil, os militantes comunistas, sob a orientação do PCB, deveriam colher quatro milhões de assinaturas. A campanha começou em março de 1950 e deveria se encerrar em 30 de setembro, data de entrega das cotas de todos os países participantes do congresso.

\section{Imagens do apocalipse}

Iniciada a campanha, diversos "comitês pela paz" foram criados em cidades, bairros e empresas brasileiras. Em sua maioria eram constituídos por comunistas e simpatizantes, que eram orientados sobre a política "pacifista" da União Soviética. Os comunistas dedicados à campanha faziam comícios, organizavam comitês, formavam "comandos". A tarefa central era a coleta de assinaturas. Os militantes deveriam dedicar-se ao máximo para que a cota fixada fosse atingida. $\mathrm{O}$ sucesso da campanha, relatava a imprensa comunista, não residia, porém, simplesmente na coleta de assinaturas, e sim num bem maior e mais glorioso. A paz no mundo e a salvação da humanidade seriam as verdadeiras conquistas dos "combatentes da paz". Dessa maneira a imprensa comunista incentivava seus leitores e, principalmente, os militantes, na busca de assinaturas. Os jornais comunistas relatavam também a adesão, sempre crescente, de pessoas que assinavam o Apelo de Estocolmo.

As mulheres eram incentivadas a participar, a se organizar em associações, a realizar palestras, comícios-relâmpago etc. Acreditavam os comunistas que a participação feminina era indispensável. Havia reproduções do Apelo de Estocolmo impressas nos jornais para que os leitores pudessem recortar e pedir a assinatura de parentes, amigos ou colegas de trabalho. Um desses modelos era destinado especialmente às mulheres:

\section{Você,}

que não quer que seu filho morra na guerra

que não quer perder seu noivo

filhos,

$$
\text { que ama seu marido e deseja que ele viva ao lado de seus }
$$


assine e mande para nossa Redação este apelo em favor da defesa da Paz entre os povos:

Exigimos a proibição absoluta da arma atômica, arma execrável e de extermínio em massa de populações.

Exigimos o estabelecimento de um controle internacional para assegurar a aplicação desta medida.

Consideramos que o governo que utilizar contra qualquer outro país a arma atômica cometerá um crime contra a humanidade e será tratado como criminoso de guerra.

(ass.)

Tire cópias desta importante resolução do Comitê Mundial dos Partidários da Paz e com ela consiga o maior número possível de assinaturas, enviando-nos em seguida. (Voz Operária, 1/4/1950, p. 4)

Já mais adiante, em seu Manifesto de Agosto, Luiz Carlos Prestes também faria um apelo especial às mulheres. Acreditando em sua força e coragem, diria:

Mulheres do Brasil! Sois as primeiras e as maiores vítimas da guerra e do terror fascista. Operárias e camponesas, donas de casa, mães e esposas. Sois vós que primeiro sentis as agruras produzidas pela fome em vossos lares. Com vossa tradicional coragem e decisão impedi o crime de mais uma guerra imperialista! (Voz Operária, $5 / 8 / 1950$, p. 1,2 e 4$)$

É interessante notar a maneira como os comunistas, através da imprensa, formulavam seus "apelos". Eis outro exemplo:

Você é contra este crime?

Uma única bomba atômica jogada sobre a cidade japonesa de Hiroshima matou 200 mil pessoas - homens, mulheres e crianças, indiscriminadamente - numa população de 400 mil habitantes.

Você deseja que outras cidades, e, quem sabe, sua própria cidade com seu lar, seus entes queridos, seus amigos tenham o mesmo trágico destino de Hiroshima? 
Não! Você, se é um ser humano, não deseja que se repita este crime contra qualquer cidade ou população.

Então, recorte e assine este apelo dos Partidários da Paz, ou tire cópias dele e faça seus amigos e companheiros de trabalho assiná-las e depois remeta-as à nossa redação - Av. Rio Branco, 257, sala 1711, Rio, D F - que as encaminharemos à Organização Brasileira de Defesa da Paz. (Voz Operária, 24/4/1950)

Com isso, os “combatentes da paz" foram conseguindo um número cada vez maior de assinaturas logo nos primeiros meses da campanha. Alguns dados divulgados pela imprensa comunista demonstravam o sucesso alcançado. Em uma reportagem, lia-se que "todos os operários de uma fábrica exigiam a proibição da bomba atômica" (Voz Operária, 10/6/1950). O exemplo vinha de Santo André, em São Paulo, onde os operários da indústria metalúrgica Nizan haviam assinado o Apelo de Estocolmo. Continuava o jornal, dizendo que "os operários dessa fábrica, unanimemente, sem nenhuma exceção, assinaram o apelo em que milhões de homens, mulheres, jovens e crianças do mundo inteiro estão exigindo a proibição da arma atômica, arma terrorista de destruição de vidas humanas, de eliminação de populações pacíficas".

Em outra matéria, referente à vila Calumbi de Flores, em Pernambuco, ${ }^{1}$ informava-se que "todos os habitantes, sem exceção, assinaram o Apelo de Estocolmo exigindo a interdição da mais hedionda arma que ameaça a humanidade" (Voz Operária, 1/6/1950). A partir desse tipo de notícia, é possível perceber a adesão de um número crescente de pessoas à Campanha pela Proibição das Armas Atômicas. Entretanto, causa certa estranheza a adesão de todos os habitantes de uma vila, "sem exceção". Deve-se lembrar que um dos objetivos da imprensa era tensionar os militantes. A notícia sobre Calumbi revela que, se algo tão improvável fora conseguido pela militância pernambucana, em outras regiões também seria possível obter o mesmo resultado. Outra questão a ser considerada é que as regiões Norte e Nordeste do país apresentavam um elevado número de analfabetos. Assim, é impressionante que todos os habitantes de uma vila tivessem assinado o Apelo de Estocolmo. Importa ressaltar que, para aqueles que não podiam assinar devido ao analfabetismo, os militantes comunistas assinavam a rogo. Em centenas de panfletos pesquisados, foi possível perceber que a letra era a mesma em nomes diferentes, assim como o material usado para a escrita (lápis ou caneta). Uma hipótese é que os comandos entrassem nas casas e um membro da família assinasse por todos. Na verdade, não se tratava de assinaturas, e sim de nomes escritos, já que havia nomes de pessoas de uma mesma família espalhados nos ta- 
lões de coleta. Convém destacar que, quando os apelos eram enviados para instituições políticas, obtinham-se verdadeiras assinaturas. Assim, não seria incorreto supor que o número de assinaturas divulgado pela imprensa comunista pudesse estar sendo inflacionado, no intuito de fazer com que a militância redobrasse seus esforços para atingir a cota fixada.

De posse de dados científicos, relatos da imprensa nacional e internacional, depoimentos de sobreviventes, os militantes comunistas, através de comandos, comícios-relâmpago, palestras, panfletos que quotidianamente distribuíam pelas ruas das cidades e, sobretudo, através de sua imprensa, procuravam alertar e esclarecer as pessoas sobre o que era a bomba atômica e quais seriam as conseqüências de uma guerra nuclear. Em um panfleto intitulado "Já pensou bem o que significa uma guerra atômica? Então medite no seguinte", ${ }^{2}$ procuravam esclarecer o poder de destruição da bomba atômica, comparando as cidades japonesas por ela atingidas no final da Segunda Guerra com cidades brasileiras. Segundo o panfleto, "uma só bomba atômica, a que foi lançada sobre a cidade de Hiroshima no Japão matou 80 mil pessoas (número equivalente a toda a população de Maceió, capital de Alagoas) e estropiou mais de 200 mil pessoas (número equivalente a toda a população de Belo Horizonte, capital de Minas Gerais).”

Os panfletos eram bastante simples e didáticos, compostos, em grande parte, de perguntas e respostas. O objetivo era explicar de maneira direta os enormes danos causados pela bomba atômica e suas radiações, e provocar impacto nos leitores. Além de revelar os efeitos destruidores das bombas atômicas jogadas em Hiroshima e Nagasaki, os panfletos também descreviam seus terríveis efeitos sobre cidades, fábricas ou praças brasileiras, caso houvesse uma guerra atômica e fossem lançadas bombas sobre esses lugares. Num deles, questionava-se em letras garrafais o que aconteceria se fosse jogada uma bomba atômica sobre uma indústria. Imediatamente após, vinha a resposta:

Se uma bomba atômica cair sobre a fábrica Goodyear, tudo que estiver a 200 metros desse ponto será arrasado e dissolvido pelo calor. A destruição será maciça até 1.600 metros desse mesmo ponto; e até 4.800 metros de distância do ponto onde cair a bomba produzir-se-á um tal aquecimento que se registrarão incêndios em massa; além disso, os efeitos da radiação ou matarão imediatamente as pessoas que estiverem nessa área ou atingirão os centros vitais de uma grande maioria, vindo a causar-lhe a morte mais tarde. ${ }^{3}$

O panfleto prosseguia mencionando bairros e outras fábricas que poderiam ser atingidos pelos efeitos da bomba atômica. Terminava dizendo que onde 
havia, naquele momento, "produção e vida seria o reino da destruição e da morte".

Na verdade, o que faziam os comunistas, em suas comparações de Hiroshima e Nagasaki com cidades brasileiras, era mostrar que, numa nova guerra mundial, as principais vítimas seriam as "populações pacíficas" das grandes cidades. Os objetivos dos provocadores de um novo conflito internacional - ou seja, os Estados Unidos e seus aliados - eram, a seu ver, claros: "eliminar vidas humanas." Merece destaque o fato de que os jornais da grande imprensa não explicavam o que eram a bomba atômica e seus efeitos. Os comunistas, nesse sentido, davam um importante esclarecimento à população sobre uma arma que, a partir do final da Segunda Guerra Mundial, mudaria o rumo das relações internacionais e poria o mundo em constante alerta.

Por outro lado, ainda em março de 1950, O Fornal, órgão dos Diários Associados de Assis Chateaubriand, apresentou uma manchete alarmante: "Impossível a defesa da Europa" (O fornal, 17/3/1950, p. 6). No artigo que se seguia, o ex-primeiro-ministro britânico Winston Churchill advertia para o "perigo crescente de uma agressão russa" e conclamava uma ação decidida do governo inglês para impedir os horrores de uma nova conflagração internacional. $\mathrm{O}$ dirigente conservador dizia no Parlamento que, sem a ajuda efetiva da Alemanha Ocidental, não se poderia defender com êxito a Europa Ocidental de uma possível invasão russa. Suas declarações causaram polêmica no cenário internacional, já que estava falando de uma Alemanha que havia posto o mundo em uma guerra catastrófica e dispendiosa para o povo europeu. Contudo, para Churchill, o temor de uma invasão da União Soviética era maior que o do rearmamento alemão, e assim como ele muitos apostavam nessa idéia. Em outras palavras, o medo de uma invasão soviética, junto com seus países "satélites", povoava o imaginário daqueles que pretendiam manter relações político-econômicas com os Estados Unidos ou estavam sob sua área de influência. Vale lembrar que o crescimento dos partidos comunistas em todo o mundo e suas vitórias nas eleições parlamentares em diversos países contribuíam em grande medida para a confirmação e a reprodução daquele imaginário. Segundo Churchill,

a decisão de estabelecer uma frente na Europa contra uma possível invasão russa e de seus Estados satélites é de suma gravidade para nós e também imperiosa. Acredito necessário dizer, falando pessoalmente e expressando opinião própria, que esta longa frente não poderá ser defendia com êxito sem a ajuda ativa da Alemanha Ocidental. (...) Não podemos assegurar aos alemães que seu território não será invadido pelos russos ou seus satélites. A poderosa massa do exército russo e 
seus satélites ameaçam o povo alemão como uma nuvem ominosa e os aliados não podem dar-lhe proteção. (Ibidem)

Sempre com um tom alarmante, o ex-primeiro-ministro britânico enfatizava o avanço comunista pelo mundo e a possibilidade real de uma terceira guerra mundial desencadeada pela União Soviética. Se nenhuma ação prática fosse decidida a curto prazo, se nenhum acordo de paz fosse eficazmente realizado, ou se a Alemanha Ocidental não fosse logo remilitarizada, o mundo inteiro reviveria os reveses de uma guerra mundial nuclear. A esse respeito Churchill prevenia: "neste terreno da bomba atômica a nossa situação piorou desde a terminação da guerra, isto porque os russos obtiveram o segredo da bomba atômica e, diz-se, começaram sua produção" (Ibidem).

Ao ler os artigos publicados na imprensa comunista, nos panfletos distribuídos nas ruas e nos boletins internos do partido destinados à orientação da militância, pode-se se perceber que os dirigentes soviéticos procuravam apresentar a União Soviética como a verdadeira defensora da paz. Desde o final da Segunda Guerra Mundial, os soviéticos preocupavam-se com a segurança do mundo, e principalmente em defender as populações pacíficas, como era dito insistentemente em sua imprensa. As nações do mundo inteiro não estariam seguras se não houvesse uma proposta cabal e definitiva de controle da energia atômica. Os Estados Unidos, possuidores de bombas atômicas, não estariam dispostos a parar nem mesmo a reduzir sua produção. Dessa forma, a partir do pós-guerra, e sobretudo no decorrer da primeira década da Guerra Fria, os comunistas passaram a apresentar-se como baluartes da paz, criando com isso todo um imaginário de "verdadeiros defensores da paz mundial". Nesse sentido, a partir de 1947, a União Soviética viabilizou a construção de um novo mito, o do pacifismo soviético, criando um conjunto de símbolos, crenças e imagens acerca de um país envolvido cabalmente na preservação da paz.

A arma atômica e seus efeitos povoavam o imaginário dos comunistas brasileiros. Para eles, a bomba "era um instrumento de agressão e extermínio em massa de populações pacíficas" e "matava indistintamente". A Guerra da Coréia, deflagrada em junho de 1950, representava o perigo iminente de uma guerra nuclear, pois, como alegava a imprensa comunista, as duas potências em confronto possuíam armas atômicas. Dessa maneira, como revela Baczko, pode-se notar que o imaginário social informa acerca da realidade, ao mesmo tempo que constitui um apelo à ação, a um determinado tipo de comportamento. $\mathrm{O}$ imaginário social é um esquema de interpretação e, também, de valorização. O imaginário suscita a adesão a um sistema de valores e intervém de modo eficaz na sua interiorização pelos indivíduos, modelando os comportamentos, capturando as energias e, em caso de necessidade, arrastando os indivíduos para uma ação co- 
mum (Baczko, 1985). Raoul Girardet afirma que é ao longo das linhas de mais forte tensão social que se desenvolvem os mitos, principalmente os políticos. Segundo o autor, “é nos 'períodos críticos' que os mitos políticos afirmam-se com mais nitidez, impõem-se com mais intensidade, exercem com mais violência seu poder de atração" (Girardet, 1987:180).

Os mitos tensionam e, ao mesmo tempo, atraem. Assim, torna-se possível perceber a adesão de um número cada vez maior de pessoas que colocaram suas assinaturas no Apelo de Estocolmo. A bomba atômica e seus efeitos devastadores povoavam o imaginário dos militantes comunistas e informavam acerca da realidade que estava por vir. Num momento de grave tensão internacional, em que as duas superpotências enfrentavam-se e hostilizavam-se mutuamente, a Guerra da Coréia simbolizava, no imaginário comunista, o início de confrontos mundiais que levariam ao fim da humanidade. Dessa maneira, existindo a possibilidade cada vez mais premente de um conflito mundial nuclear, os comunistas deveriam canalizar suas energias em prol de uma necessidade comum e de um bem maior para todos: a coleta de assinaturas para o Apelo de Estocolmo.

\section{O redobrar de esforços}

Ao ler os artigos divulgados na imprensa comunista - e até mesmo os citados ao longo deste trabalho - a impressão que se tem é que a Campanha pela Proibição das Armas Atômicas no Brasil foi desde o início um verdadeiro sucesso. Tudo indicava que os militantes em pouco tempo alcançariam ou mesmo ultrapassariam a cota de assinaturas cuja coleta deveria se encerrar em 30 de setembro. Fotografias de personalidades nacionais e internacionais eram destacadas pelos jornais comunistas no ato de assinatura do Apelo de Estocolmo; experiências dos leitores eram divulgadas com freqüência; Câmaras Municipais condenavam a arma atômica; religiosos apoiavam o movimento em favor da paz; trabalhadores de diversos setores da economia e de diferentes camadas sociais aderiam à campanha através de suas organizações sindicais, associações etc. Notícias sobre a coleta de assinaturas no mundo inteiro também eram constantemente relatadas, a fim de demonstrar o crescente desenvolvimento da campanha e corroborar as expectativas dos militantes brasileiros. A Voz Operária tinha mesmo uma seção dedicada às notícias internacionais da "Campanha pela Interdição das Bombas Atômicas", intitulada "A campanha de assinaturas".

Assim, como noticiava o jornal em maio de 1950, "na Alemanha, na pequena cidade de Furth, onde o objetivo inicial era de recolher 10.000 assinaturas, estas chegaram a 15.000. Na Comuna de Stuthurge a população assinou o Apelo de Estocolmo na proporção de 80 por cento" (Voz Operária, 20/5/1950). O jornal 
trazia ainda uma pequena tabela, mostrando os resultados em outras cidades da Alemanha. Em Dusseldorf, em $1^{\circ}$ de maio, haviam sido recolhidas 38 mil assinaturas; em Colônia, 30.600; em Essem, 28.000; em Nuremberg, 38.000 e em Munique, 22.000. Na Romênia e na Bulgária, até a primeira quinzena de maio, haviam sido coletadas 19 milhões de assinaturas contra a bomba atômica. Ainda na Romênia, destacava o jornal,

existem 237.000 voluntários recolhendo assinaturas para o Apelo de Estocolmo em favor da proibição da bomba atômica. São operários, camponeses, estudantes, sacerdotes, soldados e jornalistas. Dessa tarefa participam homens e mulheres, rapazes e moças, que vão às fábricas, às repartições, aos escritórios comerciais, de casa em casa. (Ibidem)

É possível notar que a campanha não apenas angariava milhares de assinaturas, como conquistava novos “combatentes da paz". A crença na vitória movia a militância, fornecendo-lhe o ânimo necessário para a busca incansável de mais adesões. Assim como o mito da inevitabilidade da revolução que levaria o mundo do capitalismo ao socialismo, o mito do pacifismo soviético direcionava os comunistas no caminho da vitória da paz. De acordo com Reis Filho (1989: 108), "as organizações comunistas brasileiras cultivariam com dedicação o mito da revolução inevitável". Sendo a revolução um destino, era de se esperar uma visão sempre otimista. Era "uma lei natural". Sob essas circunstâncias, afirma o autor, para os comunistas, "em momentos cruciais, sempre prevalece a confiança na vitória".

Motivados por essa esperança, ou mesmo certeza, muitos militantes se dedicavam cada vez mais às suas tarefas. Esforços solitários eram revelados no decorrer da campanha, a fim de convencer o leitor a tornar-se um "combatente da paz" e conseguir assinaturas junto aos colegas de trabalho, amigos, parentes etc. Os exemplos individuais mostravam aos militantes comunistas que as barreiras deveriam ser superadas. A tarefa de coletar assinaturas para o Apelo de Estocolmo era seu dever principal, não devendo outras questões interferir em seu curso. Assim, podia ser lido na imprensa que:

Uma violinista, partidária da paz, incumbida de tocar a Marcha Nupcial, durante um casamento em uma igreja do Distrito Federal, levou consigo diversos exemplares do Apelo de Estocolmo. Finda a cerimônia, a violinista aproveitou o ambiente de fraternidade reinan- 
te, e se dirigiu a cada um dos presentes. Ao apresentar o apelo, lembrou que a utilização da bomba atômica ameaçava a felicidade e a vida do jovem casal.

Foram unânimes as adesões ao Apelo de Estocolmo. (Voz Operária, 24/6/1950)

O militante comunista não deveria "vacilar" em nenhum momento. Qualquer situação que presenciasse em seu quotidiano era uma oportunidade de angariar mais assinaturas, contribuindo não apenas para a campanha, mas para a consolidação da paz.

O êxito da campanha, no entender dos dirigentes comunistas, dependia do sucesso da militância. Com isso, a direção partidária eximia-se de um possível fracasso na obtenção da cota esperada. Todavia, se os quatro milhões de assinaturas fossem obtidos, a vitória seria do partido, pois teria sido sob sua liderança que os militantes teriam alcançado seus objetivos. Isso fazia parte do que Reis Filho chamou de "complexo da dívida". Nesse contexto, o partido é a encarnação de uma vontade coletiva, politicamente organizada, é o detentor de um saber maior, porque científico e social. Ao ingressar no partido, integrando-se e fazendo parte de uma vontade coletiva, o militante assume, por um lado, sensações e noções de superioridade. Portanto, distingue-se das pessoas comuns. Possui um saber especial - o marxismo-leninismo - e um poder dele decorrente sobre as pessoas e os acontecimentos. Por outro lado, afirma o historiador,

O militante sabe - mais ou menos conscientemente (e o Partido o lembrará freqüentemente) - que sua superioridade é relativa, porque deriva, única e exclusivamente, do Partido. O saber e o poder de cada militante são dádivas do Partido e da vida partidária. Por maiores que sejam suas capacidades, o militante nunca deverá esquecer duas coisas: suas prerrogativas e conhecimentos jamais se igualarão às prerrogativas e conhecimentos do Partido e, em segundo lugar, foi sua inserção no Partido que tornou possível adquirir o que possui. (Reis Filho, 1989: 124)

Percebe-se aí a compreensão de uma inferioridade que vai marcar o militante em relação ao partido por toda a sua vida partidária. A figura do débito, pode-se dizer, sempre estruturou a prática social dos comunistas. "Incorrendo em erros, [o militante] terá faltado ao Partido, deverá acerto de contas, autocríticas. Nas vitórias, não terá senão cumprido o dever revolucionário e aplicado a li- 
nha do Partido" (Idem, ibidem). Com isso, os militantes deveriam superar todas as dificuldades, transpor todos os obstáculos e honrar a dádiva que lhes fora concedida. Atingir suas cotas de assinaturas na campanha contra as bombas atômicas era, naquele momento, a maneira de honrar parte de sua dívida para com o Partido.

No entanto, a partir de julho de 1950, começaram a surgir artigos e depoimentos de personalidades ligadas ao PCB questionando o atraso no recolhimento de assinaturas e pedindo que fossem redobrados os esforços para superar os obstáculos e atingir a cota desejada. Nesse momento, tornaram-se freqüentes na Voz Operária manchetes como: "Reforçar a luta em defesa da paz" (8/7, p. 11), "A resposta imediata aos agressores imperialistas: cobrir rapidamente a quota de quatro milhões" (15/7, p. 12), "Superemos imediatamente o atraso na Campanha Contra a Arma Atômica" (22/7, p. 12), "É preciso redobrar os esforços para atingir os quatro milhões" (29/7, p. 12), "Recolher rapidamente os quatro milhões de assinaturas" (5/8, p. 4), "Indispensável uma virada na campanha pela coleta dos quatro milhões de assinaturas" $(12 / 8$, p. 12). Os artigos lembravam que até então tinham sido recolhidos dois milhões de assinaturas e exigiam mais esforços dos militantes, confirmando que era necessário completar a cota no curto tempo restante. Para a militância, a palavra de ordem era "aumentar o ritmo de colheita de assinaturas". Os patrocinadores da campanha pediam aos coletores que aproveitassem o momento de tensão proporcionado pela Guerra da Coréia, divulgada por toda a imprensa, para alertar as pessoas do perigo iminente de uma guerra nuclear e dar aos hesitantes convicções para assinar. Para os dirigentes de células, não contava se o militante estava capacitado para a tarefa, nem existiam limites para o seu cumprimento - era necessário cumpri-la. Da mesma forma, nenhuma outra questão deveria se sobrepor à Campanha pela Proibição das Armas Atômicas. Segundo suas palavras, "cada partidário da paz, cada patriota consciente tem o dever de honra de trabalhar infatigavelmente para que o município e o Estado em que resida cubram e ultrapassem essas cotas" (Voz Operária, 1/7/1950, p. 1).

Em meados de agosto, em um texto amplo intitulado "Por uma reviravolta na luta pela proibição da arma atômica", Jacob Gorender enumerava os problemas que envolviam a campanha e apontava possíveis soluções. A seu ver, a campanha de assinaturas havia marcado alguns êxitos importantes no país. Devido aos quase dois milhões de assinaturas, ficava demonstrado que a vontade de paz era muito viva no seio do povo, não tendo havido necessidade de excessivo esforço para despertá-la e fazer com que se manifestasse. Contudo, era impossível deixar de constatar que o número de assinaturas coletadas estava muito aquém dos quatro milhões que o movimento comunista propusera atingir nacionalmente até fins de setembro. Gorender criticava, assim, o ritmo em que se estava desenvolvendo a campanha e a fraca propaganda usada pelos militantes: 
Torna-se inadiável, assim, uma revisão geral nos planos de trabalho, visando o seu aceleramento. A média diária de assinaturas recolhidas precisa aumentar, o que, por sua vez, impõe maior número de visitas de casa em casa, de comandos às empresas, de caravanas pelo interior, de viagens às fazendas a fim de as assinaturas dos camponeses, etc. (...) Até agora, a propaganda pela campanha pela proibição das armas atômicas tem sido muito débil. Em alguns pontos do país, ela se restringe quase inteiramente ao esforço do jornal popular local. (Voz Operária, $19 / 8 / 1950)$

Após afirmar que, em todo o Brasil, a propaganda havia sido insatisfatória, Gorender fazia uma crítica aos militantes de base explanando: "podemos dizer que os partidários da paz ainda não se convenceram da necessidade de elevar a sua propaganda ao nível da propaganda eleitoral ou ainda acima dele, tanto no que toca ao volume como à rapidez e à variedade" (Ibidem). A boa propaganda, que se refletiria sem demora na conquista das massas, deveria cobrir três requisitos básicos: "quantidade, qualidade e variedade". Concluía afirmando que "qualquer fracasso só pode se explicar pela incapacidade de fazer uma coisa simples: ir às massas, apelar para o seu apoio criador" (Ibidem).

Aqui também se percebe que os militantes de base seriam os verdadeiros responsáveis por não se atingir a cota nacional. Eles é que deveriam se dirigir às massas, entrar em contato com jovens, homens e mulheres, fazer conferências, comícios, festivais etc. Segundo a lógica intrínseca ao PCB, o fracasso era atribuído aos militantes, que não se mostravam capazes de cumprir suas tarefas. $\mathrm{O}$ sucesso pertencia ao partido, que, com destreza e sabedoria, soubera conduzir o conjunto para a vitória. Entretanto, é preciso destacar que os militantes não eram meras correias de transmissão da direção do partido e que, embora a direção fizesse questão de lembrar a inferioridade do militante em relação à instituição partidária, muitos deles ousaram e arriscaram, cumprindo à sua maneira ou até mesmo descumprindo determinadas orientações da direção. É o caso, por exemplo, dos militantes que estavam ligados ao setor sindical.

É sabido que os comunistas eram o segmento político mais organizado no interior do movimento sindical. Pode-se observar, através de uma série de estudos já produzidos sobre o tema, que desde antes do Estado Novo os comunistas desenvolviam um trabalho incansável de organização e mobilização de sindicatos. Esse enraizamento no interior dos movimentos sociais, como revela Hélio da Costa (1995: 28), "traduziu-se numa prática que referendava o caráter de liderança exercido por muitos ativistas comunistas nas ações grevistas por um lado, $\mathrm{e}$ por outro sinalizava futuras divergências com os dirigentes do partido". De fato, como as fontes podem demonstrar, havia militantes de base e até mesmo dirigen- 
tes que não concordavam com algumas das posições defendidas pela direção do partido, e questionavam, criticavam e/ou simplesmente não cumpriam as determinações delas oriundas. Eloy Martins, líder metalúrgico de Porto Alegre, assim comentou, por exemplo, sua incompreensão diante da política conciliadora do

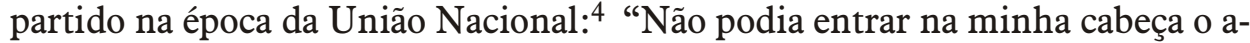
poio irrestrito a Vargas e posteriormente à política de 'apertar o cinto' para evitar greves" (1989: 77). Do mesmo modo, Eduardo Dias relatou sua experiência com o que chamou de "posição negativa em relação à greve". Para ele, "a tal palavra de ordem de apertar o cinto e outras tantas" não passavam de "incoerências" (1982: 58). Esses relatos permitem refletir sobre o impacto de uma política da direção do partido contrária aos movimentos das classes trabalhadoras. Muitos militantes realmente não sabiam o que fazer. Ou melhor, sabiam que deveriam seguir as orientações de sua direção, mas alguns se recusavam a fazê-lo. Foi o caso de Hércules Corrêa. De acordo com o militante, "nós, que trabalhávamos nos sindicatos, no dia-a-dia e na prática, estávamos cada vez mais distantes do pensamento da direção. E aqui é preciso deixar uma coisa bem clara: o PCB não era, nunca foi, apenas a sua direção" (2005: 81).

Assim, é possível perceber que, quando as diretrizes da direção do partido não encontravam terreno fértil junto ao militante de base, a realidade vivenciada pelo militante fazia-o rever suas posições e, com isso, refletir e interpretar as orientações da direção. Isso fica evidente quando se compara o número de Comitês Pró-Paz criados em 1950 com o número de Comitês da Frente Democrática de Libertação Nacional (FDLN) ${ }^{5}$ criados no mesmo ano. Como demonstram as fontes, havia centenas de comitês ligados às campanhas pela paz, enquanto os comitês da FDLN não passavam de pouco mais de uma dezena (Ribeiro, 2008). Nesse sentido, não se pode ver a relação do PCB com os seus militantes apenas como uma relação de força-coação. Em inúmeros casos, muitos militantes contestaram as ordens oriundas do núcleo dirigente e tomaram atitudes práticas que consideravam mais condizentes com a realidade que vivenciavam.

Chegado afinal o dia 30 de setembro, data da entrega das assinaturas dos milhões de "patriotas" brasileiros que apoiaram a luta contra as armas atômicas, é interessante observar que a imprensa comunista não mencionou em suas páginas informações sobre o resultado da campanha. De toda forma, é possível calcular que até então foram colhidos pouco mais de dois milhões de assinaturas. Devido ao resultado, o prazo de entrega foi prorrogado para 13 de novembro, pois de 15 a 19 daquele mês seria realizado o II Congresso Mundial da Paz em Sheffield, Inglaterra. Os patrocinadores da campanha convocaram então para os dias 21, 22 e 23 de outubro o II Congresso Brasileiro dos Partidários da Paz, durante o qual foi instituída a "Quinzena da Paz", com o objetivo de recolher o restante das assinaturas. Os militantes comunistas, mais uma vez, foram concla- 
mados ao redobrar esforços. Contudo, no decorrer dos preparativos para o Congresso da Inglaterra, uma decisão surpreendeu os "partidários da paz" de todo o mundo: o governo inglês não autorizou a realização do congresso em seu país. Os responsáveis rapidamente transferiram o encontro de Sheffield para Varsóvia, na Polônia, no período de 16 a 23 de novembro. No dia 18 de novembro, a $\mathrm{Voz}$ Operária publicou na primeira página um artigo sobre a participação do Brasil no II Congresso Mundial da Paz em que se lia:

A defesa da paz é a mais nobre tarefa de nosso tempo. Nessa jornada histórica de todos os povos, o Brasil ocupa um lugar de destaque. Nossos 4 milhões de assinaturas ao Apelo de Estocolmo, já assegurados antes dos resultados finais da Quinzena Nacional de Assinaturas, significam considerável contribuição à causa da paz.

Curiosamente, no mesmo dia, em sua página 4 - aquela reservada aos assuntos do Movimento da Paz e da Campanha pela Proibição das Armas Atômicas -, o jornal publicou um artigo intitulado "Tarefa imediata: atingir e ultrapassar os 4 milhões." Na semana seguinte, mais uma vez, podia-se ler o título "Atingir e ultrapassar os 4 milhões de assinaturas" (Voz Operária, 25/11/1950). Ao menos uma pergunta pode ser feita: por que dizer que era preciso atingir os quatro milhões, se na primeira página da edição do dia 18 o jornal congratulava os "combatentes da paz" brasileiros pela conquista da tarefa antes mesmo do final da "Quinzena da Paz"? As informações eram desencontradas. Mesmo que a cota de quatro milhões tivesse sido alcançada, causa estranheza a rapidez com que teriam sido obtidos os quase dois milhões de assinaturas faltantes. Do início da campanha, na segunda metade do mês de março, até 30 de setembro - quase sete meses - os partidários da paz tinham conseguido dois milhões e quinhentas mil assinaturas. Considerando-se que 12 de novembro foi a data de encerramento da "Quinzena da Paz", torna-se surpreendente que em tão curto espaço de tempo aproximadamente 45 dias - tivesse sido completada a cota brasileira.

Em dezembro, os jornais comunistas divulgaram as resoluções do congresso realizado em Varsóvia, reunindo 79 países. Segundo esses relatos, "500 milhões de pessoas em todo o mundo assinaram o Apelo de Estocolmo exigindo a proibição da bomba atômica como arma de guerra e considerando criminoso de guerra contra a humanidade o governo que primeiro utilizar a bomba atômica contra qualquer país" (Voz Operária, 2/12/1950). Ao comparar esses números com os apresentados no I Congresso Mundial da Paz, realizado em Paris e Praga em 1949, mesmo o leitor menos atento percebe um ponto controverso. Segundo os documentos do I Congresso, que reuniu 72 países, havia 600 milhões de "com- 
batentes da paz" organizados - portanto, menos países e mais 100 milhões de militantes. Nas palavras de Fernando Claudin, "nesta imponente cifra figuravam todos os 'combatentes da paz' da URSS, China e demais democracias populares, onde o simples fato de pertencer ao gênero humano era condição suficiente para ficar inscrito no inflamante exército pacifista" (1970: 528). Em resumo, nos resultados do II Congresso, descontando-se os 400 milhões de assinaturas dos países comunistas, onde as listas eram uma "obrigação" do cidadão, os 100 milhões obtidos nos 69 países do Ocidente demonstram o pouco êxito da campanha. Os "combatentes da paz" reduziam-se aí, com ligeiras variantes, aos efetivos dos partidos comunistas e das organizações de massas por eles controladas (sindicatos, associações femininas, juvenis, culturais etc.). Mesmo que tenha havido a participação de personalidades não atreladas ao movimento comunista, ligadas ao mundo esportivo, científico, artístico etc., deve-se relativizar esses dados. Os patrocinadores da campanha inflacionavam publicitariamente o número de assinaturas, cuja exatidão era extremamente difícil de controlar, produzindo a impressão de que o movimento fora um verdadeiro sucesso e ultrapassara o âmbito político e social constantemente influenciado pelos comunistas. É preciso salientar que as questões não se desenvolveram exatamente como propagavam os comunistas, e que os meios dirigentes tinham consciência disso.

\section{Considerações finais}

Os comunistas brasileiros sem dúvida conseguiram coletar um bom número de assinaturas e conquistar diversas personalidades não-comunistas para sua campanha. Além de personalidades internacionais, de modo geral pouco conhecidas no Brasil, os jornais comunistas mostraram a adesão de brasileiros que tinham posição de destaque na sociedade, entre eles o ministro Álvaro Moutinho Ribeiro da Costa, do Supremo Tribunal Federal; o general Leitão de Carvalho; o senador Mathias Olímpio (UDN); os deputados Plínio Barreto (UDN), Campos Vergal (PSP) e Gurgel do Amaral (PTB); o padre João Batista de Carvalho; o professor Pedro Pernambuco Filho, da Faculdade Nacional de Medicina, representante da América Latina na Seção de Combate aos Tóxicos da Unesco; o criminalista Evandro Lins e Silva; o arquiteto Oscar Niemeyer, autor do projeto da sede da ONU; o escritores Aníbal Machado, Aparício Torelly, Adalgisa Nery e Jorge Amado; o sociólogo Caio Prado Júnior; o etnólogo Édison Carneiro; os jornalistas Edmar Morel e Pedro Mota Lima; o pianista Arnaldo Estrela; os pintores Di Cavalcanti, José Pancetti, Candido Portinari e Clovis Graciano; Alvaro Moreyra, presidente da Associação Brasileira de Escritores; o regente Camargo Guarnieri; Alice Tibiriçá, presidente da Federação das Mulheres do Brasil; Va- 
lério Konder, sanitarista; Roberto Gusmão, representante da UNE no Conselho da União Internacional dos Estudantes; Salomão Malina, ex-combatente da FEB e membro do Conselho da Federação Mundial da Juventude Democrática; frei Ludovico, provincial dos franciscanos de São Paulo; o cientista Cesar Lattes; artistas como Mara Rúbia, Cacilda Becker, Vera Nunes, Gregório Barrios e Nhô Totico; radioatores como Leonor Navarro, Gessy Fonseca, Mário Lago e Lia de Aguiar; a educadora Branca Fialho.

No entanto, para a população de maneira geral, não houve repercussão maior que a das assinaturas dos integrantes da seleção brasileira de futebol de 1950. Os jornais comunistas aproveitaram-se da oportunidade da entrevista com os "craques" e divulgaram sua assinatura em página inteira. O técnico da equipe brasileira, Flávio Costa, ao ser abordado pela reportagem da Imprensa Popular (24/6/1950) justificou a posição dos esportistas afirmando: "Assinarei o Apelo de Estocolmo com muito prazer. [...] Acho que a guerra e o esporte são duas coisas antagônicas. A guerra só serve para dividir os povos. O esporte, ao contrário, serve para uni-los". O artigo prosseguia confirmando que, "seguindo o exemplo de Flávio, todos os titulares da Equipe Nacional, e mais o pessoal técnico que a acompanhava, assinaram entusiasticamente o Apelo de Estocolmo. Nem um só deles se recusou ou sequer vacilou em dar sua assinatura em favor da Paz". O periódico fez questão de estampar uma reprodução do apelo, com o nome dos jogadores e membros da comissão técnica que o assinaram. Ao final, conclamava todos os "combatentes da paz" - entenda-se, em sua maioria militantes comunistas - a aproveitar a reportagem ao abordar as pessoas para, além de mostrar que a campanha não era do PCB nem em prol dele, assim conseguir colher mais assinaturas.

Não se pode esquecer que, independentemente dos resultados da campanha, os comunistas, então na clandestinidade, e sob forte repressão política e policial, conseguiram mobilizar diversos setores da sociedade. Políticos, religiosos, estudantes, esportistas, intelectuais, trabalhadores, todos foram abordados em seu quotidiano e convencidos a ceder suas assinaturas em prol da campanha. Além disso, foi realizado um importante trabalho de divulgação sobre a bomba atômica e seus efeitos. A opinião pública, em sua maior parte, desconhecia os assuntos relativos às armas nucleares. Foi através da imprensa comunista, dos comícios-relâmpago, dos congressos, dos panfletos distribuídos de casa em casa, das palestras, das dramatizações, entre outros meios de divulgação, que a população, de uma maneira geral, ficou conhecendo o que era uma bomba atômica e suas conseqüências. Assim, torna-se necessário relativizar a frustração do esforço dos comunistas brasileiros. Os militantes, mesmo atuando clandestinamente, conseguiram angariar um impressionante número de assinaturas e conquistar diferentes personalidades de diversos setores da sociedade, mantendo-se assim ligados à vida política do país. 
Vale lembrar que o presidente Eurico Gaspar Dutra, durante todo o seu mandato (1946-1951), tratou o movimento dos trabalhadores de forma arbitrária e severa, com uma política repressiva verdadeiramente feroz. No início, a linha política do PCB era "manter a ordem" e não entrar em choque contra o governo. A cassação do registro do partido em 1947 e do mandato de seus parlamentares em 1948 causou enorme impacto interno. A perseguição policial que o PCB passou a sofrer partir daquele momento frustrou todas as suas expectativas de uma evolução eleitoral dentro da lei. A partir de então, o partido alterou sua linha política, dando uma virada radical à esquerda e propondo a luta armada revolucionária como solução para os problemas do país. Essa nova linha política foi consolidada em 1950, com o lançamento do Manifesto de Agosto, e se estendeu, pelo menos oficialmente, até 1958, quando o partido voltou a pregar uma linha moderada e de luta por reformas.

No início dos anos 1950, portanto, de acordo com Marco Aurélio Santana (2001: 70), demonstrando ambigüidade, o PCB "intentava, assim, articular a luta pela paz no âmbito internacional com a luta pela revolução internamente”. Sem dúvida isso pode ser visto como uma contradição relevante. Mas para o PCB, ou ao menos para a sua direção, uma luta não anulava a outra. De acordo com o pensamento comunista daquele momento histórico, e com o seu programa de ação, a paz só seria obtida com a implantação do socialismo, e este só seria alcançado, segundo o Manifesto de Agosto, pela via das armas. Havia certamente, da parte de diversas personalidades no interior do partido, uma resistência à radicalização. Além disso, havia uma enorme dificuldade de pôr em prática o viés radical no governo Dutra. Estabelecido o alinhamento do governo brasileiro com o norte-americano, os comunistas eram hostilizados, perseguidos e reprimidos política e policialmente. Segundo Santana, mesmo com sua nova postura política de radicalidade, e apesar da crítica ao espaço de atuação institucional e da autocrítica por tê-lo priorizado no momento da legalidade, o PCB demonstrava valorizar esse espaço e desejar retornar a ele: "diante da cerrada repressão, pensava o partido, estes espaços poderiam servir para dar-lhe fôlego" (Ibidem).

Dessa maneira, entre o chamamento à revolução e a busca de uma atuação nos meios legais e institucionais, entre a guerra revolucionária e a luta pela paz, os comunistas procuravam envolver-se em campanhas e movimentos de diferente natureza a fim de continuar participando da vida política do país e não se desestruturar a ponto de se extinguir enquanto instituição política. Como destaca o militante comunista Moisés Vinhas (1982: 96), o que impedia os comunistas de desaparecer como força política efetiva era "provavelmente sua participação em campanhas pela paz, contra a bomba atômica, na qual consegu[iam] reunir milhares de assinaturas". Tais campanhas, afirma o militante, mantinham "algumas franjas de sua política ligadas à realidade do país”. 
1. Consultando-se o IBGE, verifica-se que Calumbi pertence à zona do sertão alto de Pernambuco. Em divisões territoriais datadas de 31/12/1936 e $31 / 12 / 1937$, figurava no município de Flores o distrito de São Serafim. Todavia, pelo decreto-lei estadual $\mathrm{n}^{\circ} 92$, de 31/3/1938, o distrito de São Serafim passou a se denominar Calumbi. Em divisão territorial datada de 1/7/1960, o distrito de Calumbi permaneceu no município de Flores. Contudo, em 20/12/1963, foi elevado à categoria de município, pela lei estadual $\mathrm{n}^{\circ} 4.938$, e desmembrado de Flores. O censo de 1950 revela que Calumbi tinha então 3.875 habitantes, enquanto o município de Flores possuía 39.548.

2. Arquivo Público do Estado do Rio de Janeiro (APERJ), Departamento de Política Social (DPS), Panfleto 717, ano de 1950.

3. Arquivo Nacional. MJ/Segurança Nacional. Panfletos Ij1 1325, ano de 1950.

4. Em agosto de 1943, o PCB realizou sua II Conferência Nacional, conhecida como

\section{Referências bibliográficas}

Conferência da Mantiqueira. Naquele encontro, o partido formalizou sua nova linha política, pela qual ficou estabelecido que todos os brasileiros deveriam cerrar fileiras ao lado do governo Vargas para derrotar o nazi-fascismo. Os comunistas também deveriam dar apoio incondicional à política de guerra travada pelo governo e lutar pela anistia, pela normalização institucional do país e pela legalização do PCB. Além disso, a direção do PCB traçou uma linha política de não-enfrentamento com o governo; no que concerne à realização de greves, conclamou os trabalhadores a evitá-la e a "apertar os cintos". A nova orientação política do partido ficou conhecida por União Nacional.

5. A Frente Democrática de Libertação Nacional foi a política do PCB para organizar uma ampla frente democrática, na linha do Manifesto de Agosto (1950-1958), cujo objetivo era organizar a sociedade para alcançar a "libertação do país do jugo imperialista" por intermédio da luta armada.
BACZKO, Bronislaw. Imaginação social. In: Enciclopédia Einaudi. Anthropos-Homem. Lisboa: Imprensa Nacional/Casa da Moeda, 1985. vol. 5.

BETHELL, Leslie \& ROXBOROUGH, Ian. (org.). A América Latina entre a Segunda Guerra Mundial e a Guerra 
Fria. Rio de Janeiro: Paz e Terra, 1996.

CARONE, Edgar. O PCB. São Paulo: Difel, 1982. vol. 2.

CLAUDIN, Fernando. La crisis del movimiento comunista. De la Komintern al Kominform. Paris: Ruedo Ibérico, 1970.

COSTA, Hélio da. Em busca da memória: comissão de fábrica, partido e sindicato no pós-guerra. São Paulo: Scritta, 1995.

DIAS, Eduardo. Um imigrante e a revolução. São Paulo: Brasiliense, 1982.

FERREIRA, Jorge. Prisioneiro do mito: cultura e imaginário político dos comunistas no Brasil (1930-1956).

Niterói: Eduff/ Rio de Janeiro:

Mauad, 2002.

HOBSBAWM, Eric J. Era dos extremos. O breve século XX: 1914-1991.

São Paulo: Companhia das Letras, 1995.

MANIN, Bernard. Paz. In: Enciclopédia Einaudi. Anthropos-Homem. Lisboa: Imprensa Nacional/Casa da Moeda, 1985. vol. 5 .
MARTINS, Eloy. Um depoimento político (55 anos de PCB). Porto Alegre, 1989.

REIS FILHO, Daniel Aarão. A revolução faltou ao encontro. Os comunistas no Brasil. São Paulo: Brasiliense, 1989.

. Entre reforma e revolução: a trajetória do Partido Comunista no Brasil entre 1943 e 1964. In:- e RIDENTI, Marcelo (orgs.). História do marxismo no Brasil. Campinas: Editora da Unicamp, 2002. vol. 5.

RIBEIRO, Jayme Lúcio Fernandes. Guerra e paz: a trajetória dos comunistas brasileiros nos anos 1950. Niterói, Universidade Federal Fluminense (UFF), 2008. Tese de doutorado.

SANTANA, Marco Aurélio. 2001. Homens partidos: comunistas e sindicatos no Brasil. Rio de Janeiro: Boitempo.

STRATHERN, Paul. Oppenheimer e a bomba atômica em 90 minutos. Rio de Janeiro: Jorge Zahar, 1998.

THOMPSON, E. P. (org.). Exterminismo e Guerra Fria. São Paulo: Brasiliense, 1985.

\section{Resumo}

O trabalho procura reconstituir a Campanha pela Proibição das Armas Atômicas, adotada pelo PCB no ano de 1950. Seguindo a linha pacifista da União Soviética, dirigida a todos os partidos comunistas, a campanha consistia no recolhimento, pelos militantes comunistas, de assinaturas a um apelo pela proibição da utilização das armas atômicas por qualquer país e pela eliminação dos arsenais atômicos existentes até aquele momento. Os comunistas brasileiros, mesmo na ilegalidade, articularam-se e obtiveram o apoio de diferentes grupos sociais à campanha.

Palavras-chave: comunismo, PCB, paz, imaginário social, bomba atômica, Apelo de Estocolmo. 


\section{Abstract}

The article describes the Campaign for the Banning of Atomic Weapons, sponsored by Brazilian Communist Party (PCB) in 1950. Following the pacifist line proposed by the USSR to all communist parties in the world, the campaign consisted in gathering signatures on petitions calling for the absolute banning of atomic bombs. Brazilian communists, even in illegality, organized themselves and conquered the support of different social groups to the campaign.

Key words: communism, PCB, peace, social imaginary, atomic bomb, Stockholm Appeal.

\section{Resumé}

L'article décrit la Campagne pour la Prohibition des Armes Atomiques, adoptée au Brésil par le Parti Communiste (PCB) en 1950. Suivant la ligne pacifiste proposée par l'Union Soviétique à tous les partis communistes, la campagne consistait à le recueillir des signatures sur des pétitions revendiquant l'interdiction de l'utilisation des armes atomiques par n'importe quel pays et l'élimination de tous les arsénaux atomiques. Les communistes brésiliens, même dans l'illégalité, se sont organisés et ont obtenu l'appui des différents groupes sociaux à la campagne.

Mots clés: communisme, PCB, paix, imaginaire social, bombe atomique, Appel de Stockholm 